\title{
DETERMINING CRITERIA FOR EVALUATING THE EFFICIENCY OF THE EDUCATION IN A DISTANCE LEARNING PLATFORM
}

\author{
Milena Kuleva \\ National Sports Academy "Vassil Levski”, Sofia, Bulgaria
}

Summary: In the modern conditions of continuous educational process, the nature, the role, the methods and the technologies of training at universities are changing. This study aims to offer objective criteria for evaluating the efficiency of the distance learning process of sports specialists through a distance learning platform.

Key words: evaluation criteria, efficiency, distance education, e-learning platform

Introduction: In order to evaluate the efficiency of the eLearning, a number of models have been developed that cover a wide range of indicators such as: return of the investments, organization of the learning process, interests of the parties involved in the process and learning outcomes. (Scriven, 1991) (Holton, 1996) (Yonjoo Cho, 2009) (Khan, 2005) (Rosenberg, 2001) (Schreurs, 2008). In 1954, Kirpatrick created a model for assessing the efficiency of the education, which is one of the most widely used models today. Initially, the model was created to assess the efficiency of the staff training for the business, and today it is successfully used to evaluate non-traditional forms of training. The model has 4 levels of evaluation.

Another widely used model for evaluating the efficiency of eLearning is CIPP (Context input process product evaluation). Key areas in the evaluation of the training effectiveness are measurement and analysis of the indicators "effectiveness, efficiency and relevance of education. "The CIPP model uses "critical" indicators to measure the efficiency of eLearning. It contributes, on the one hand, to the continuous improvement of the educational process and, on the other hand, proves the value of the training of the interested parties.

Another model that is important to mention is that of Khan (Khan, 2005). He developed a model to assess the effectiveness of eLearning program, which is based on two dimensions. In the first dimension, he focuses on the elements of the process of e-learning - people, materials, processes and products of the training.

The second dimension is related to the e-learning process itself - its design, support for the educational process and the delivery of e-courses. (Eva García, 2012)
We believed, that none of the examined models was suitable for the evaluation of the effectiveness of the distance learning in the National Sport Academy "Vassil Levski" and therefore, we have set the aim to offer objective criteria for assessment the effectiveness of the distance learning process.

Methodology: Based on the analysis of the foreign experience, as well as the detailed analysis of the existing evaluation models and the main components of the education in the NSA online platform, we developed a questionnaire with indicators assessing the effectiveness of the eLearning platform of NSA. (Osika E., 2005) (Piccoli G., 2001). The research was done among 45 lecturers - involved as experts in the evaluation and ranking criteria for efficient learning. We used Variation analysis, Comparative $\mathrm{t}$-criterion of Student ( $\mathrm{Pt} \geq 95 \%$ ), and Frequency analysis. The calculated sum of the frequencies was multiplied by the corresponding weight factor $(3,2$ or 1), depending on the ranking order of the proposed indicators. (Levy, 2006)

The results were processed with variance analysis, which allowed us to determine the average scores of the experts for each of the defining indicators, as well as the dispersion around them of the individual cases. It should be noted that Asymmetry (As) and Excision (Ex) calculations, in general, are within the normal range, which is evidence of a normal distribution. This allows us to make accurate analyzes and generalizations. (Гигова, 1999) (Гигова, 2002)

Results: The analysis of Table1 shows, that as a result of the observed differences of the experts' opinions, the dispersion of the individual estimates around the average for each indicator is relatively stable. The only exception occurred in the 10th indicator. This area of dispersion is the widest $(\mathrm{V} 10=34,67 \%)$. 
Table 1.

Average values and variability of the estimates on the surveyed indicators

\begin{tabular}{|c|c|c|c|c|c|c|}
\hline № & Indicators & $\mathbf{X}$ & $\mathbf{S}$ & V & $\min$ & $\max$ \\
\hline 1. & Students' satisfaction with the learning process in platform & 8,20 & 1,41 & 17,17 & 5 & 10 \\
\hline 2. & Usefulness of the acquired knowledge according to the students & 8,40 & 1,62 & 19,23 & 4 & 10 \\
\hline 3. & Practicality of the material & 7,67 & 2,23 & 29,03 & 3 & 10 \\
\hline 4. & Topicality of the study material & 9,20 & 1,31 & 14,21 & 4 & 10 \\
\hline 5. & Quality of teaching & 8,69 & 1,50 & 17,32 & 5 & 10 \\
\hline 6. & Presentation of educational materials in the platform & 8,84 & 1,40 & 15,80 & 5 & 10 \\
\hline 7. & Online communication between student and lecturer & 8,76 & 1,57 & 17,92 & 4 & 10 \\
\hline 8. & Accessibility of the learning materials and resources & 8,91 & 1,44 & 16,20 & 5 & 10 \\
\hline 9. & Activity of the students in the platform & 7,98 & 1,47 & 18,42 & 4 & 10 \\
\hline 10. & Attrition from the learning process & 5,98 & 2,07 & 34,67 & 2 & 9 \\
\hline 11. & Interest in learning & 8,16 & 1,54 & 18,84 & 4 & 10 \\
\hline 12. & Students' success (final mark) & 8,00 & 1,49 & 18,66 & 4 & 10 \\
\hline 13. & Flexibility of the learning & 8,53 & 1,50 & 17,60 & 4 & 10 \\
\hline 14. & Theoretical orientation of the material & 8,13 & 1,70 & 20,90 & 4 & 10 \\
\hline 15. & Convenient virtual environment (platform) & 8,89 & 1,48 & 16,66 & 5 & 10 \\
\hline
\end{tabular}

It was also observed that there are serious differences in terms of 3rd indicator. However, the value of the coefficient of variation V $(\mathrm{V} 3=29,03 \%)$ enables us to assume that this indicator is relatively stable, the group of the investigated experts - relatively homogeneous, about the possibilities of the online learning to provide a high practical orientation of the study material. In the analysis of the Table 1, it is also noteworthy that the average scores on the determined indicators vary between 9.20 points (at the 4 th indicator - "Topicality of the study material") and 5.98 points (for the 10th indicator - "Attrition from learning process "). It is also observed that the relative shares of the obtained maximal scores are of the highest value (10 points) for the 4th, 8th and 15th indicators, these are "Topicality of the study material", "Accessibility of the learning materials and resources" and "Convenient virtual environment (platform)".

This fact, in general, is also confirmed by the ranking of the indicators proposed by us (Table 2).

Frequency analysis results multiplied by weight ratios

(according to surveyed experts)

\begin{tabular}{cccccc}
\hline $\begin{array}{c}\text { Indicator } \\
\text { № }\end{array}$ & Arrangement & Points & $\begin{array}{c}\text { Frequency of indicators Frequency of indicators Frequency of indicators } \\
\text { placed at I place }\end{array}$ & placed at II place & placed at III place \\
\hline 1. & 12 & 8 & 1 & 2 & 1 \\
\hline 2. & 7 & 20 & 5 & 4 & 3 \\
\hline 3. & 9 & 17 & 2 & 6 & 3 \\
\hline 4. & 1 & 36 & 7 & 1 & 3 \\
\hline 5. & 2 & 26 & 7 & 5 & 3 \\
\hline 6. & 3 & 26 & 4 & 6 & 4 \\
\hline 7. & 8 & 20 & 1 & 7 & 4 \\
\hline 8. & 4 & 24 & 2 & 3 & 4 \\
\hline 9. & 11 & 13 & 1 & 2 & - \\
\hline 10. & 15 & 3 & 1 & 1 & 6 \\
\hline 11. & 10 & 16 & 2 & 3 & 1 \\
\hline 12. & 14 & 6 & 1 & 2 & 3 \\
\hline 13. & 5 & 23 & 4 & 2 & - \\
\hline 14. & 13 & 7 & 1 & 5 \\
\hline 15. & 6 & 22 & 5 & & 3 \\
\hline
\end{tabular}

The analysis of the table shows that the 10th indica- the literature that we study, it is proven that the attor has received lowest number of points (3 points) trition of the learners who study through electronic which is related to the possibility of students' attri- (online) form is most often due to the poor comtion from the learning process. Such low ratings on munication between the teacher and the learner this indicator is something unexpected, because in and the inadequate communication between the 
learners themselves, which directly affects their motivation to learn and the degree of satisfaction with the work done (Cobb, 2012). Moreover, the use of distance studies platforms and different web based courses offer an innovative teaching method which increases students' participation motivation and enhances their interest towards the particular subject (Doncheva, 2015).

The 12th and 14th indicators have also received lower ratings (respectively 6 and 7 p.). This gives us reason to believe that some experts do not attach great importance to indicators such as the theoretical orientation of the materials and the final grade on the module, regarding the possibilities of online learning.

The analysis of the results from the study of the opinion of the experts, involved in the study, makes it possible to propose a theoretical model for evaluating the effectiveness of the learning process (Кулева, 2016), through the web-based platform, which corresponds to the needs of the NSA "Vassil Levski" (Table 3).

Theoretical model to assess the effectiveness of the learning process according to the web-based platform of NSA "Vassil Levski"

\begin{tabular}{|c|c|c|}
\hline \multicolumn{2}{|c|}{ № Indicator } & Name of the indicator \\
\hline 1. & 4 & Topicality of the study material \\
\hline 2. & 5 & Quality of teaching \\
\hline 3. & 6 & $\begin{array}{l}\text { Presentation of educational materials } \\
\text { in the platform }\end{array}$ \\
\hline 4. & 8 & $\begin{array}{l}\text { Accessibility of the learning materials } \\
\text { and resources }\end{array}$ \\
\hline 5. & 13 & Flexibility of the learning \\
\hline 6. & 15 & $\begin{array}{l}\text { Convenient virtual environment (plat- } \\
\text { form) }\end{array}$ \\
\hline 7. & 2 & $\begin{array}{l}\text { Usefulness of the acquired knowledge } \\
\text { according to the students }\end{array}$ \\
\hline 8. & 7 & $\begin{array}{l}\text { Online communication between stu- } \\
\text { dent and lecturer }\end{array}$ \\
\hline
\end{tabular}

Discussion and conclusion: The efficiency indicators provide a basis for assessing the quantitative efficiency of the system. The experts most probably do not consider that students' dropping out of the educational process is related to the efficiency of the education itself, but rather to other personal reasons. We believe that students' dropping out of the learning process is most often due to both poor communications between the lecturer and the learner and insufficient communication between the learners themselves that directly affects their motivation to learn and the level of satisfaction with the work done. The analyses made enable us to propose a theoretical model for evaluating the efficiency of the educational process, which would meet the needs of NSA "'V. Levski".

The effectiveness of the learning process, according to experts, is mostly determined by the platform's capabilities to ensure the relevance of learning material, accessibility to learning materials and resources, and a user-friendly virtual environment (platform).

There are significant differences in expert judgment regarding the relevance of the learning material that can be provided through the web-based platform and the opportunities for attrition from the learning process of students which are taught through this platform.

We believe that it is necessary in the future to trace the question of attrition from the learning process by examining the possible reasons for this, both in attendance education and in distance (online) learning.

We are sure that the platform provides opportunity for highly efficient preparation for the theoretical subjects. The skillful combination between the different forms of education will undoubtedly raise the quality of the education process in all universities, including the National Sports Academy.

\section{References}

Cobb, T. P., 2012. NETWORKED LEARNING: EVALUATING THE EFFECTIVENESS OF DISTANCE EDUCATION IN COMPARISON TO TRADITIONAL EDUCATION. Dissertation.. s.l.: Louisiana State University: Louisiana State University.

Eva García, A. G.-C. M. K., 2012. Analysis of standards and specifications of quality and accessibility in e-learning. Loja (Ecuador), Actas del IV Congreso Internacional ATICA 2012.

Holton, E. F., 1996. The flawed four level evaluation model.. 1 ed.s.l.: Human Resource Development.

Khan, B., 2005. Managing E-learning: Design, delivery, implementation and evaluation.. 1 ed. Hershey, PA: Hershey PA: Information Science Publishing..

Levy, Y., 2006. Assessing the Value of E-Learning Systems.. 1 ed.s.1.: Science Information Publishing..

Osika E., D. C., 2005. Concentric Model for Evaluating 
Internet-Based Distance Learning Programs.. s.l., 18th Annual Conference on Distance Teaching and Learning. Piccoli G., R. A. B. I., 2001. „Web-based virtual learning environments: A research framework and a preliminary assessment of effectiveness in basic IT skills training.. MIS Quarterly, December, pp. 401-426.

Rosenberg, M. J., 2001. E-learning: Strategies for delivering knowledge in the digital age.. 1 ed. New York: McGraw Hill.

Schreurs, J., 2008. TQM in e-learning: A Self-Assessment Model and Questionnaire.. s.l.: Institute of Information Theories and Applications FOI ITHEA.

Scriven, M., 1991. Beyond formative and summative evaluation.. 1 ed. Chicago: University of Chicago Press. Yonjoo Cho, S. P. C.-W. J. S. J. J. D. H. L., 2009. Developing an Integrated Evaluation Framework for E-Learning. Long Beach, USA: s.n.

Гигова, В., 1999. Статистическа обработка и анализ на данните със SPSS. 6.1. Базова статистика.. София: HCA.

Гигова, В., 2002. Статистическа обработка и анализ на данни - учебно помагало.. София: НСА.

Кулева, М., 2016. Управление на интерактивна платформа за обучение на специализирани спортни кадри. DIssertation.. София: s.n. 